\title{
INDIAN POLITICO-RELIGIOUS EXTREMISM AND KASHMIR: A STUDY OF MODI's INDIA
}

\author{
Arslan Bin Shahid \\ M.Phil Degree in Peace and Conflict Studies \\ Master's degree in Art and Science of Warfare \\ National Defence University, Islamabad. \\ arslanbinshahid@gmail.com \\ Dr Lubna Sunawar, \\ Assistant Professor \\ Faculty of Contemporary Studies \\ National Defence University, Islamabad. \\ lubnasunawar@ndu.edu.pk
}

\begin{abstract}
Individual or group identities based upon religion are able to cause political activation affecting cogency of governments and their policies. Imprint of religion on state's politics affect the secularity of any federation and thus has the capacity of impact the existing political complexities and conflicts rooted in religious and political identities. The rationale of this research paper is to analyze if Indian oscillatory political behaviour fits neatly into the theoretical framework of Johan Galtung's Conflict Triangle. The research paper seeks to (i) analyze radicalization of Indian society on the basis of Hindutva, (ii) validates that Indian politics transitioned from secularity to extremism under Modi's Hindutva Nationalism and (iii) Indian political radicalization has worsened the already precarious situation of Kashmir Conflict. The paper in light of given framework fills the existing niche that Indian political extremism has transformed a relatively non-conflictual situation into a fully brewed conflict.
\end{abstract}

Key Words: Hindutva, Kashmir, Religion, Politics, Contradictions, Attitude, Behaviour, Conflict Triangle. 


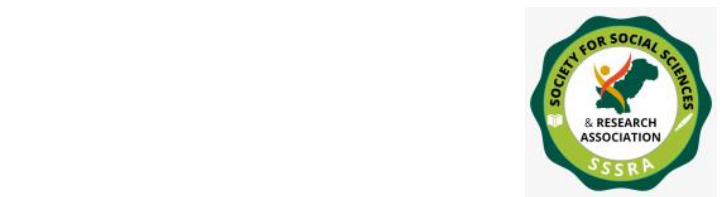

Pak. Journal of Int'L Affairs, Vol 4, Issue 2 (2021)

Indian Politico-Religious Extremism ...

\section{Introduction}

It is often difficult to isolate religion from politics even in the most avowedly secular societies and the likelihood of religion affecting the politics is very high (Walker, 2011). The co-relation between religion and politics is therefore a very vivacious subject in philosophy of politics, irrespective of the tacit agreement for the distinction between religion and state (Callaway, 2009). It is established that peoples' commitment and devotion is often dictated by religion even for the universal religions who do not assert to come into conflict with the demands of politics and claim to incorporate whole of human race and governance paradigms rather than a selected group or community. Islam, for instance claims that different politico-cultural practices can be accommodated in a singular model offered by it. The West on the contrary, faced a complex social problem in ascertaining as to what extent plurality of religious beliefs can be accommodated in their politico-cultural milieu?. Callaway, (2009) endorsed John Locke's argument mentioned in "A Letter Concerning Toleration" that:-

- Coercion of people's belief is pointless as they cannot willingly accept or reject propositions.

- Control on religious practices should not be exercised as long as they interfere with the rights of others.

- One religious group might not get strong enough to challenge the state's functioning till other groups are also at liberty to practice their own religion.

Religion is considered to be a foundation of political advancements (Fox, \& Sandler, 2003). Carolyn C James and Özgür Özdamar are of the opinion that the prominent impact of religion is the capability to strengthen or weaken rightfulness of governments (James, \& Özdamar, 2005). However, Marxist explanation recognizes association among legality of the state and religion while labelling religion as "means by which political actions are facilitated by the dominant classes." (Rogers, \& Konieczny, 2018). Therefore, it can be concluded that individual or group identity of religion is able to cause political activation which can effect cogency of governments and policy (Harris, 1994).

India owing to its rich history and vibrant social construct breeds one of the most diverse religious and cultural structures (Fuller, 2000). Without deliberating upon the discussion of the claimed oldest democracies of 'The Sabhas and The Samities' which existed in primeval India (Bhat, 1954), democratic and political history of India can clearly be divided into following four distinct eras:- (Sharma, 1989).

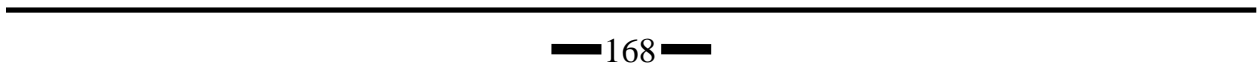




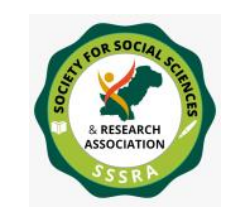

Pak. Journal of Int'L Affairs, Vol 4, Issue 2 (2021)

Indian Politico-Religious Extremism ...

- Indus valley civilization to the emergence of Islam.

- Up till War of Independence - 1857.

- 1857 to 1947.

- 1947 onwards.

There has always been a deep imprint of religion in Indian politics; the nature, intensity and dynamics of this interplay however differed in each phase (Sharma, 1989). British legacy of Pre-Partition politics, gradually tailored to suit interests of respective communities bearing different cultural and religious identities left a clear mark on the evolution of political process of India. Religion, which despite the rhetoric of secularity, occupied an important part in constituting the outlook of modern day India (Sharma, 1989). It continues to be a vital ingredient of today's Indian political stance and dominated lately after 2014 elections where a gross rightward shift in politics and societal inclinations have given rise to extremist and hegemonic designs to overpower religious minorities and minority dominated geographical areas (Vaishnav, 2018, October 11). thereby negatively impacting the secularity of federation which was claimed to be the foundation of Indian democracy.

Kashmiri freedom struggle in the wake of these fluctuating socio-political leanings has thus become a complex phenomenon to be understood through a singular causal factor (Nadim, 2019, February 20). Taking a lead from geographical and religious precursors; the ethnic divide and identity crisis at state and sub-state level all combine together to compound the issue. Religious polarization coupled with extremist religious and political stances continue to form the basis of all these discrepancies which divide the Kashmiri society and create deviation of allegiances within all the factions resulting into complexity of the issue. The recent abrogation of Article 370 and 35A in violation to the United Nations resolution and introduction of Citizenship Amendment Act-2019 (CAA) are clear manifestation of Indian majoritarian mindset where space for non-Hindus, especially Muslims is being gradually squeezed (Dar, 2019).

The complex nature of Kashmir conflict therefore needs to be analyzed in the overall construct of extremist Indian politico-religious milieu. The prime objective of the research is to analyze Kashmir issue from the perspective of political extremism of Indian politics - 'Hindutva'. The study will briefly examine origin and core beliefs of Hindutva, followed by ascertaining as to how extremism crept in Indian Politics which resulted in annexing the disputed territory of Kashmir and shattered the secularity of Indian state? The oscillatory behaviour of Indian politics and constitutional dictates having direct bearing upon attitudes and behaviours of society and state alike will be analyzed from the prism of Johan Galtung's 'Conflict Theory - ABC Triangle' (Galtung, 1996). which is a 
simple structure for exploring the causes, origin and layout of a conflict and can be used to answer the Kashmir conundrum at both Indian State and sub-state level. Underlying context of these clefts and its impact on attitudes and behaviour of Indian populace and government will be analyzed in the paper adopting qualitative research while taking the lead from the assertion made by Johan Galtung that "a conflict should always be taken as a hypothesis" wherein it generates energy and can lead to constructive behaviours - a concept embedding danger vis-à-vis opportunity. (Galtung, 1996).

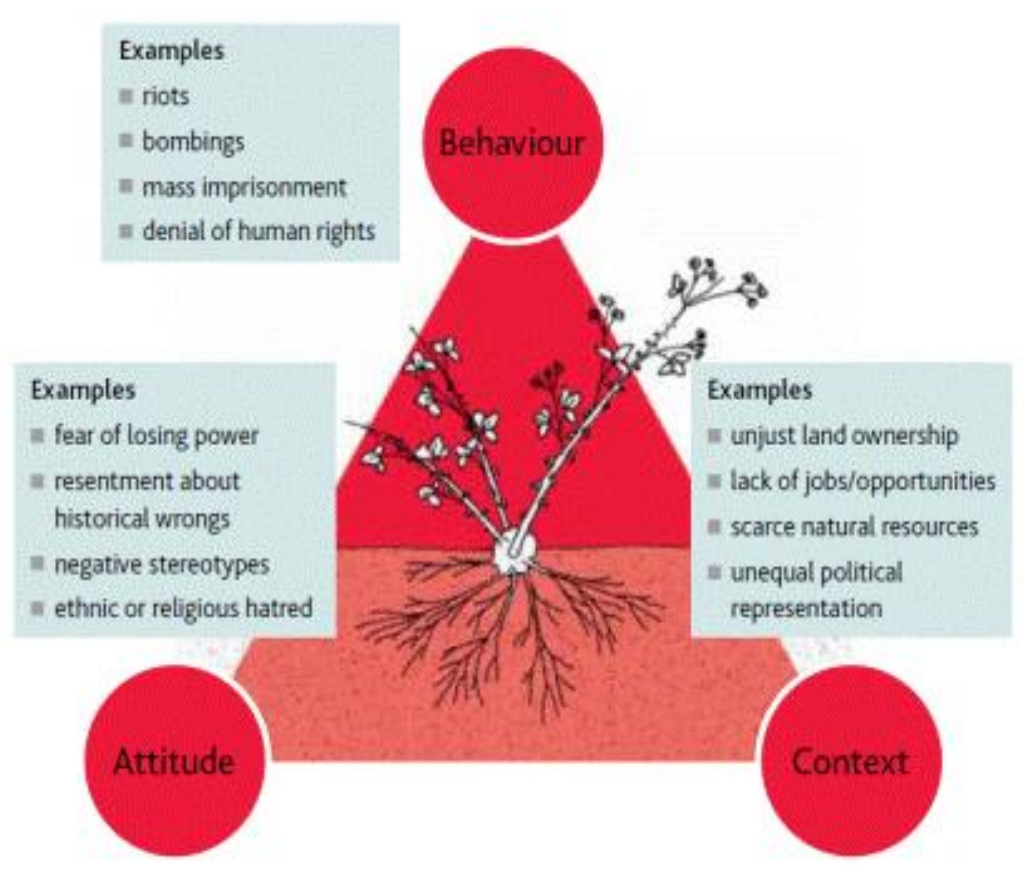

\section{Origin of Hinduism, Hindutva and Radicalization of Indian Society and Politics}

In order to analyse the context / causes of radicalization of Indian society and politics, the impact of Hinduism and Hindutva on politico-religious outlook of India must be understood, without which, shaping of attitudes and behaviours of religious forces and rise of religious extremism cannot be comprehended (Barkun, 2003). No ancient literature including Vedas, Purana, Ramayana, Mahabharata and even the great Sansikrat scholar Kalidasa has ever used the word 'Hindu' (K, T. 2018, January 9). Possibly the word 'Hindu' was created during invasion of Alexander the great to refer to the people 


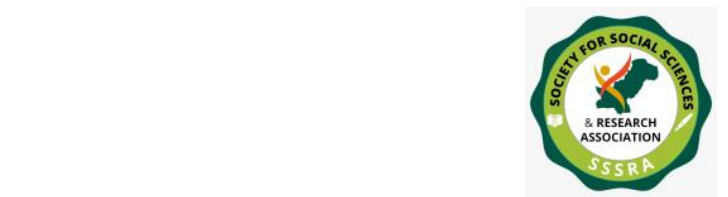

inhibiting south of the river Shindhu (River Indus) (Barua, 2018, November 17). In year 1816, Raja Rammohan Roy in his book 'Isopanisad' coined the word Hinduism for this religion equating way of worship followed by Hindus as per western concept. Thereon, the Hindus are endeavouring to defend and define these two words (Barua, 2018, November 17).

Hindutva - a key concept in 'Hindu fundamentalist ideologies' that has become pronounced recently dates back to the Hindu reform movements such as the Brahmo Samaj (1828) and the Arya Samaj (1875) which explain the notion of India as the nation of Hindus alone (Hindu Rashtra) (Lorenzen, 1995). A dual strategy of stigmatization and emulation was thus undertaken to harken back to the Vedic Golden Age to revive era of cultural prominence (Jaffrelot, 2009). Further V. D. Sarvakar, a radical Hindu and the actual architect of Hindutva formally introduced the Hindutva ideology in year 1923 thus forming the context of divide, which shaped the attitudes and behaviours of populace and governments alike (Sāvarakara, 1999). 'Hindutva India' thus manifested itself by swaying the behaviour of India as a nation and state away from secularity (Sharma, 2011).

\section{Principles of Hindutva}

Hindutva when coined as an ideology revolved around Political, Economic and Social aspects mentioned in two prominent books 'Essentials of Hindutva' and 'Essence of Hinduism' written by Savarkar and Gandhi respectively. In simplistic terms, Hindutva ideology was contextualized; aiming at progressing without forgetting the cultural roots, identity and history of common Indian lineage. Some basic principles of Hindutva at the time of inception of ideology and its present status are discussed below: (Sharma, 2002).

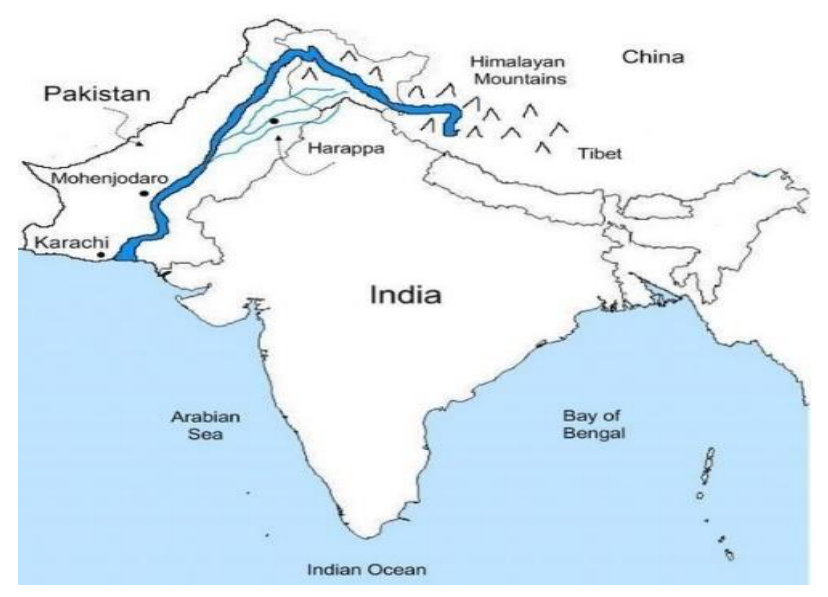




\begin{tabular}{|c|c|c|c|}
\hline Principles & Context & Attitude Forming & $\begin{array}{c}\text { Behavioural } \\
\text { Manifestation }\end{array}$ \\
\hline National Identity & $\begin{array}{l}\text { Equal treatment of } \\
\text { Hindus and all other } \\
\text { people without } \\
\text { considering their } \\
\text { religion }\end{array}$ & $\begin{array}{l}\text { - Formed the basis of } \\
\text { secularity - post } \\
\text { independence. } \\
\text { - Created division in the } \\
\text { attitudes of various } \\
\text { political parties and } \\
\text { populace (Congress } \\
\text { and Bharitixa Janata } \\
\text { Party-BJP) }\end{array}$ & $\begin{array}{l}\text { - Negative behaviour } \\
\text { manifested towards } \\
\text { non-Hindus and low } \\
\text { caste Hindus. } \\
\text { - Altered the framing } \\
\text { context of all- } \\
\text { inclusiveness. }\end{array}$ \\
\hline Cultural Nationalism & $\begin{array}{l}\text { Development without } \\
\text { forgetting Hindu ethos } \\
\text { and morals }\end{array}$ & $\begin{array}{l}\text { - Hindu dominance. } \\
\text { - Religious polarization } \\
\text { of politics. }\end{array}$ & $\begin{array}{l}\text { - Manifested with } \\
\text { extremist tendencies }\end{array}$ \\
\hline Integral Humanism & $\begin{array}{l}\text { Treating Humans as } \\
\text { "Human' not as political } \\
\text { or economic identity }\end{array}$ & $\begin{array}{l}\text { - Failed to form positive } \\
\text { attitude }\end{array}$ & $\begin{array}{l}\text { Manifested } \\
\text { polarization } \\
\text { society }\end{array}$ \\
\hline $\begin{array}{l}\text { Revoking } r \text { Voice } \\
\text { against Oppression } \\
\text { of Hindus }\end{array}$ & $\begin{array}{l}\text { All Hindus consider } \\
\text { India as their Holy } \\
\text { Land and their } \\
\text { ancestors were Indians } \\
\text { at one time }\end{array}$ & $\begin{array}{l}\text { - Concept of 'Mother } \\
\text { India' endeayouring } \\
\text { for greater influence in } \\
\text { the sub-continent. }\end{array}$ & $\begin{array}{l}\text { - Suppression of other } \\
\text { identities (especially } \\
\text { Muslims) } \\
\text { - Citizenship Bill - } \\
2019 \text {. }\end{array}$ \\
\hline
\end{tabular}

\section{Extremism of Indian Politics - From Secularity to Extremism}

Gradually, the level of Indian Secular Democracy has deteriorated and it appears that India is exhibiting extremist religious attitudes and the original concept of democracy and secularism is in jeopardy. This argument is supplemented by exhibiting of a disturbing tendency, particularly in the case of freedom of expression, alternative sources of information, rule of law, civil society, few electoral facets and strong ethno-religious inclinations which are manifested by the surge of violent actions against religious and ethnic minorities especially after political dominance of BJP post 2014 (CNBC TV. 2018, July 24). The proclamation of Ralph Winters appears to be correct where he opines that, "The Hindu World is the most perverted, most monstrous, most implacable, demonicinvaded part of the planet. There is just no question about it. The greatest, biggest, blackest, most hopeless mass of confusion, perversion, deception and oppression is this 


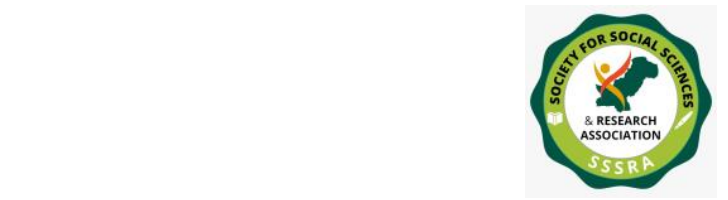

Pak. Journal of Int'L Affairs, Vol 4, Issue 2 (2021)

Indian Politico-Religious Extremism ...

massive Hindu bloc. The perversion of Satan in this part of the world is just absolutely legendary." (Ralph Winter, 1994, November 1).

It is also pertinent to highlight that the actual hinduization of Indian politics was primarily set into motion not by BJP but by the Congress party when religious card was played by Indra Gandhi after the famous "Syndicate" divided the party (Ralph Winter, 1994, November 1). Taking a lead from the congress's successful religion card, the newly conceived political party in 1980s- BJP, made the Indian political outlook take a dynamic rightward shift. "Hinduize all politics and militarize Hindudom": A slogan of Savarkar exposed myth of Hindus' non-tolerance towards other religious communities shaped the attitude and behavior of Indian society (Patnaik, \& Chalam, 1998). and abrogation of Article 370, 35A and CAA marked the darkest events on Indian political history.

\section{Hindutva Nationalism under Modi}

In order to appeal to the larger audience, BJP's election campaign of 2014 was largely focused on the issues of development, anticorruption, and good governance and was not fought on the central issues of Hindutva (Vaishnav, 2019). However, it certainly does not mean that the Hindu Nationalist theme remained absent; on the contrary, the religious nationalist narrative remained the underlying context and was spread in a targeted manner where the BJP believed that the electoral benefit can be accrued (Vaishnav, 2019). BJP's accession to power, embracing Hindu personalities and symbols to accrue maximum political mileage and resurgence signaling a shift towards religious nationalism post 2014 came as a result of accusing the Congress Party of appeasing the Indian minorities via its "pseudo-secularism" which in formers view was undertaken at the expense of the country's overwhelming Hindu majority (Jaffrelot, 2015). Modi's consecutive success in 2019 elections is manifestation of the fact that BJP has conquered a massive political territory which has made the religious nationalist agenda of this party as the center of gravity of Indian politics and made it more acceptable to masses, discrediting the secular nationalism of congress (Vaishnav, 2019). BJP thus thriving on the ideology of Hindutva has taken this religious extremism and religious nationalism to the levels equal to that of fascism and is likely to lead to bloodshed (The Nation Reporter 2020, January 26). Abrogation of Article 370 and 35A and CAA are a clear manifestation of Indian radicalized political outlook where minorities are suppressed to a limit that their existence, political, cultural and religious identities and freedom are immaterial in the attainment of the Hindu Rashtra and Akhand Bharat dream. As Paul Brass notes, "Case after case of Hindu-Muslim violence has been carefully plotted and forcefully instigated by political leaders within the Hindutva movement and the BJP." (Demerath III, 2004). The phenomenon of extremism which gained momentum in 2014 became an absolute 


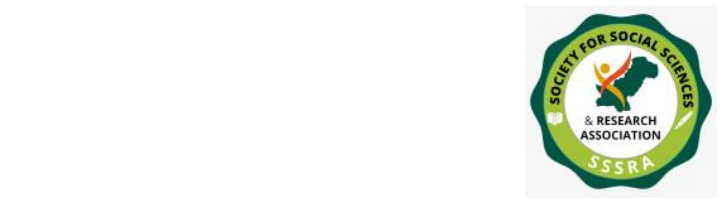

reality in 2019 elections and made India the "first of the great democracies to fall to populism" - A phenomenon which appears to be absolute and irreversible. (Taseer, 2019).

\section{Politico-Religious Extremism and Kashmir}

Revoking this special status for integration of Kashmir into India had been a demand of the BJP since long. This act was a behavioural manifestation of extremist attitude of Indian Government having a context of accruing leverages for subsequent cleansing of Muslim dominated region. The Reorganization Act-2019 paved way to inch a step further by introducing the CAA and is likely to provide two possible advantages to BJP:- (Sharma, 2019, August 19).

- $\quad$ Likelihood of gaining more political mileage in both; India and J\&K.

New Delhi may now assert that Kashmir issue is an "internal" matter of India so as to deny possible third-party mediation. (Galtung, 1996)

The protracted socio-ethnic conflict of Kashmir which rested in the latent domain of demonic context and negative attitudes of Indian politics has taken dangerous overtones where an abrupt change in behavior of India has antagonized the stakeholders at both domestic and regional levels. This conflict has also generated positive energy which galvanized the locals and leadership on one point agenda of reversal of Reorganization Act-2019 despite their internal fissures (Right of self-determination/ Annexation with Pakistan by Mir Waiz Umer and Ali Gilani's factions, Call of Independence by Yasin Malik's followers and greater autonomy by Abdullah's and Muftis). Mass imprisonments and gross human rights violations (behavior indicators of Conflict Triangle) has ignited the spirit of "Kashmiriyat" in the contradictory views of Kashmiri community. This change of Kashmiri attitudes also proves the assertion made by Johan Galtung that conflict can create positive energy and provide an opportunity which can lead to creative conflict transformation (Sharma, 2019, August 19).

The conflict when viewed through the lens of Johan Galtung's Conflict Triangle depicts a complex intertwined and connected change in attitudes and behaviours of the players involved in the conflict which had a direct bearing upon the other factor. When the $\mathrm{A}, \mathrm{B}$ and $\mathrm{C}$ oriented approaches to conflict as elaborated by Johan Galtung are applied in relation to the eight possibilities post 2014 (Galtung, 1996), the matrix clearly indicates gradual transitioning of a relatively non-conflictual situation towards a conflictual one. 


\begin{tabular}{|c|c|c|}
\hline $\begin{array}{l}\text { Indicators/ } \\
\text { Possibilities }\end{array}$ & Explanation & Timeframe / Activity \\
\hline $\mathrm{A}=0, \mathrm{~B}=0, \mathrm{C}=0$ & Absolute non-conflict & - Never existed in the BJP ideology. \\
\hline$A, B=0, C=0$ & $\begin{array}{l}\text { Attitudes/ assumptions } \\
\text { prepared }\end{array}$ & $\begin{array}{l}\text { - BJP electoral campaign of } 2014 \text { having underlying } \\
\text { Hindutva ideology }\end{array}$ \\
\hline$A=0, B, C=0$ & $\begin{array}{l}\text { Beharioural patterns } \\
\text { prepared }\end{array}$ & $\begin{array}{l}\text { - } 1^{\text {st }} \text { term of Modi in office and surge in Anti-Muslim } \\
\text { sentiment. } \\
\text { - Popular Hindu support for Anti-Muslim agendas. }\end{array}$ \\
\hline$A, B, C=0$ & $\begin{array}{l}\text { Attitudes/ assumptions } \\
\text { and behaviours } \\
\text { prepared }\end{array}$ & $\begin{array}{l}\text { - Support to Hindutva cause by Hindu population } \\
\text { - BJP's victory in } 2019 \text { elections. }\end{array}$ \\
\hline $\mathrm{A}=0, \mathrm{~B}=0, \mathrm{C}$ & Contradiction is there & $\begin{array}{l}\text { - Jargons of Indianist instead of Hinduist approach. } \\
\text { - Silence of other pol parties. }\end{array}$ \\
\hline$A, B=0, C$ & $\begin{array}{l}\text { Sub-conscious level } \\
\text { fully prepared }\end{array}$ & $\begin{array}{l}\text { - BJP's majoritarian approach } \\
\text { - Disregarding secular leaders while promoting radicals }\end{array}$ \\
\hline $\mathrm{A}=0, \mathrm{~B}, \mathrm{C}$ & $\begin{array}{l}\text { Ritualistic Conflict } \\
\text { Behariour }\end{array}$ & $\begin{array}{l}\text { - Violence against minorities } \\
\text { - Proposal of annexing disputed territory } \\
\text { - Threat of water wars }\end{array}$ \\
\hline A, B, C & $\begin{array}{l}\text { Fully articulated } \\
\text { Conflict }\end{array}$ & $\begin{array}{l}\text { - Abrogation of Article } 370 \& 35 \mathrm{~A} \\
\text { - Citizenship Act } \\
\text { - Claims on AJ\&K/ GB } \\
\text { - Fueling of border disputes basing upon concept of } \\
\text { Akhand Bharat } \\
\text { - Military terrorism in Kashmir }\end{array}$ \\
\hline
\end{tabular}

\section{(Indicators / Possibilities of Conflict Explanation)}

Revocation of special status of J\&K has complexed the already precarious geostrategic proclivities of the region where India is largely seen as perpetrator by its neighbours. Modi's government might have been compelled to expedite the abrogation of Articles $370 \& 35 \mathrm{~A}$ in the backdrop of recent geopolitical developments like expected

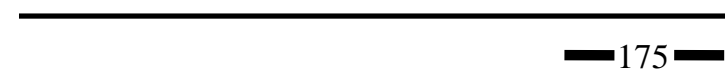




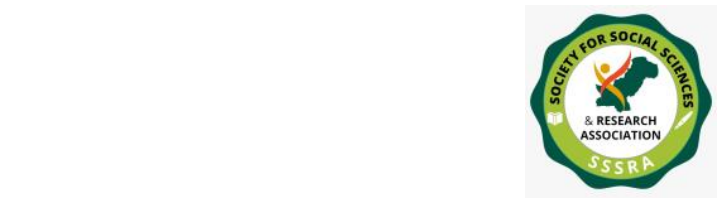

U.S. withdrawal from Afghanistan, China's growing foot print in the neighbouring countries of India, suspected resurgence of Taliban in Afghanistan and offer of mediation for resolution of Kashmir issue by U.S. President (Sharma, 2019, August 19). India now asserts that this issue will not be discussed with Pakistan as a second party as Kashmir has now become a "strictly internal matter" of India (Sharma, 2019, August 19). Furthermore, possibility of Modi's endeavor to render the current division of territory in Kashmir non-negotiable by formalizing the Line of Control can also not be ruled out. The same has even become more complex for Pakistan when India's Defense Minister Rajnath Singh suggested that any future talks with Pakistan will now be held to discuss status of Pakistan-administered Kashmir only. (Sharma, 2019, August 19) This abrupt shift in India's attitude and behavior has challenged the basic construct and context of the whole conflict as discussed by Johan Galtung that all the three facets of conflict triangle are interlinked and change in one can alter the construct of other. (Galtung, 1996) This change in latent and manifest domains of conflict called for a strong response from other belligerents and thus shaped into a fully brewed conflict; unlikely to be resolved any time soon unless all belligerents agree to step back from their Zero Sum stance (Worldview Stratfor, 2019, December 12).

\section{Analytical Prognosis}

- $\quad$ Religion has always and will continue to form part of the political outlook of India as it is embedded in the very fabric of Hindu socio-political and cultural construct. In India, interplay of religion and politics has become a dangerous phenomenon as it opposes the secularity of Indian politics. Religion encouraged passion and suspended the power of reasoning which ultimately led to violent and radicalized Indian society - akin to that of Nazism and fascism (Ali, 2021, January 13).

- Indian political outlook has taken a clear leap towards extremism. The seed of political extremism sowed by congress has now become an irrepressible giant which has engulfed the society as a whole. Therefore, a political stunt to validate BJP's rightward affinity became a compulsion for Modi as the BJP government could not fulfill its election manifesto during its first term in government (i.e 2014-19).

- $\quad$ Radicalization of Indian politics and society is manifested by spread of country wide Anti Muslim sentiments which is visible by increased violent acts of fascist Hindu radicals against Muslims and other minorities.

- Kashmir, which has caused major politico-military stirs in the region has been dealt with in three distinct governance and management phases (UCA., n.d.):-

- The first phase marked the allegiance of prominent Kashmiri political leaders with India who were mainstreamed in the politics of Valley. Construction of Indian narrative that political activities of Muslim leaders of Kashmir is in line with the union's secular 


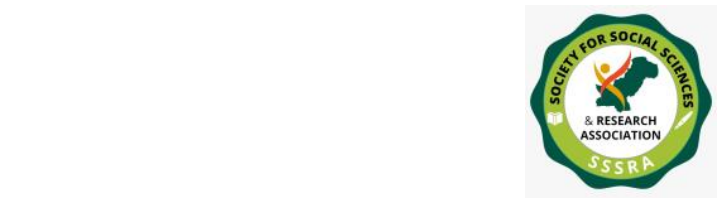

Pak. Journal of Int'L Affairs, Vol 4, Issue 2 (2021)

Indian Politico-Religious Extremism ...

outlook failed to muster support of main chunk of Kashmiri populace, especially the young generation. (UCA. n.d.).

The second phase involved militarization of the region in order to counter the violent freedom struggle with had popular local support. (UCA., n.d.) With approximately seven lac soldiers inside the valley, Kashmir became the most militarized place on earth.

The third phase which kicked off after 2014 elections reached its climax after Narendra Modi's re-election in year 2019 when he implemented his agenda of "Hindunising" India. (UCA, n.d.) Modi, invigorated by his electoral conquest of May 2019 elections, ditched the secularity of India. The change in Indian attitude thus caused an abrupt change in the socio-political behaviours and defied the chain of memory which is now being challenged by all the factions.

- Kashmir conundrum which already was a highly solution resistant conflict has further been exacerbated by the rightward shift in Indian politics and the notion of 'Conflict begets Conflict' is likely to be manifested as follows:-

Hindutva's Akhand Bharat dream cannot be materialized as long as the pre-partition Kashmir is not absorbed by India. This not only precludes possibility of formalization of the existing LOC but also projects claims on the Azad Kashmir and Gilgit Baltistan thus enhancing the probability of future conflict.

Resettlement of Hindus in the valley is clear violation of international conventions and is against the local sentiments. The same is being resented by the Muslim population of Kashmir thus brewing domestic conflict situation.

The positive energy generated by this abrupt change of status has resulted into galvanizing the local Kashmiris against Indian majoritarian mindset and has transformed the political outlook of Kashmir. India, which previously enjoyed relative political freedom in Kashmir has lost the grounds and even the pro-Indian Kashmiri politicians who once acted as Indian puppets have also taken sides with the moral anti Indian forces making the already fragile political and security situation of Kashmir more precarious. Internal fissures of All Parties Hurriyat Conference (merger with Pakistan versus independence) has also been subsided in wake of Indian political aggression.

- $\quad$ CAA, resembling the 1982 citizenship law of Myanmar which obliterated the citizenship rights of millions of the Rohingya people, offers the essential framework for extenuating anti-Muslim sentiment in India. Such fascist acts backed by highest podium of power within a state when exploited by radicalized elements result in pogroms and genocide of the targeted minorities. This draconian law possess all the possible ingredients necessary to become a Muslim eliminatory gamble.

- Religious fanaticism which mushroomed in the society under the auspices of RSS and other extremist religious organisations has now been given legitimacy and credence and is adopted as a political doctrine by BJP. This tendency has on one hand given illegitimate political and street power to the fanatic goons and on the other divided the 


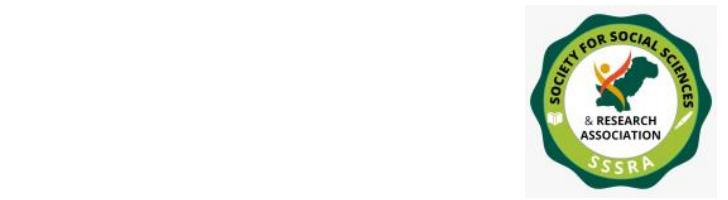

existing heterogeneous society of India. It is logically perceived that the diversity of Indian society will not be able to coup with this majoritarian trend and is set for collision in times to come.

- $\quad$ Any change in the existing narrative manifests overtime. It is likely that the division on religious and ethnic basis, implemented in today's India is likely to truly manifest in years to come. It will be after a decade or more that the true effects of today's change will be visible. If right course corrections aren't undertaken, future of Indian democracy and secularity appears to get smeared in times to come.

Peace within India and the region has been endangered by ambitious and fascist ideology of BJP which has not only caused unrest domestically but also stirred the fragile regional peace. The religious and political extremism has squeezed space for the biggest minority of the country and illegal annexation of the only Muslim majority state is a clear example of religious extremism. Peace of the region and fate of Kashmir will largely depend upon the internal situation of the valley, which for now is kept under tight noose. It is most likely that local sentiments of people residing in the valley will be highly volatile as they are continuously being suppressed by Indian government and military. This abrogation has been viewed as an external threat to the communal identity and core beliefs of Kashmiris which has directly threatened the 'Chain of Memory' of all the Muslims of J\&K. This blatant abrogation coupled with CAA has clearly busted the shell of Indian secularity and exposed the 'Hindutva' dominated fascism of Modi led government. It has also provided an opportunity to the Kashmiris to carryout inner dialogue - Kashmiris who were previously divided over the political landscape with respect to their allegiances and demands. Positivity in this conflict by all means has gone against the Indian narrative wherein, this change in status has not only jelled the divided Kashmiri community but also internationalized the conflict which was relatively quiescent at regional and international fora. Social construction of the Kashmir conundrum existing since last seven decades is now in the process of re-construction on the fault lines of religious extremism and Hindutva dominated politics. Regional players and reminiscent secular political parties must make endeavours to shun the modern fascist ideals of Indian politics so as to save the world's largest democracy from collapsing into the abyss of religious extremism and religious nationalism. Concrete steps must be taken to initially manage the conflict, paving way for subsequent resolution. All the stakeholders must shore up their diplomatic efforts to garner a supportive international milieu wherein the real cause of conflict is addressed and further damage is averted. Intra-state dialogues on possible solution of the Kashmir issue needs to be undertaken so as to formulate a narrative acceptable to all the belligerents alike. The conflict erupted by sudden change in the attitudes and behaviours of Indian political elite should be tackled by addressing the context and contradictions. 


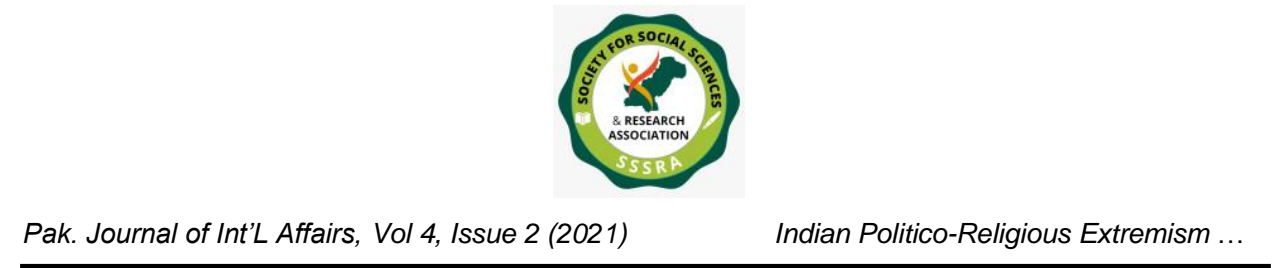

\section{References}

Ali, S. (2021, January 13). Religion and Politics in India, Preserve Articles, http://www.preservearticles.com/essay/essay-on-religion-and-politics-in-india/4957

Barkun, M. (2003). Religious violence and the myth of fundamentalism. Totalitarian Movements and Political Religions, 4(3), 55-70. https://www.tandfonline.com/doi/citedby/10.1080/14690760412331326230?scroll=top $\underline{\& n e e d A c c e s s=\text { true }}$

Barua, R. (2018, November 17). Hindu Hinduism and Hindutva - Twist of the Hindu Identity Thru the Ages, Boloji.com, https://www.boloji.com/articles/50583/hinduhinduism-hindutva

Bhat, J. N. (1954). Ancient Indian Democracies/LES Democraties Anciennes De L'inde. Civilisations, 51-59..http://www.jstor.org/stable/41377595

Callaway, C. (2009). Religion and Politics. Internet Encyclopedia of Philosophy. https://iep.utm.edu/2009/page/2/

Chandra, K. (2019). The Roots of Hindu Nationalism's Triumph in India: What BJP Learned from the Congress Party. Foreign Affairs.

CNBC TV. (2018, July 24). Future of Democracy in India in Danger Since 2014 Election, Money Control, https://www.moneycontrol.com/news/politics/future-of-democracy-inindia-in-danger-since-2014-election-says-study-2757251.html

Dar, H. N. (2019). The Rise of Hindutva and its Impact on the Kashmir Conflict. Institute for Policy Reforms. https://ipr.org.pk/wp-content/uploads/2019/08/Rise-of-Hindutvaand-its-Impact-on-the-Kashmir-Conlfict-IPR-Revised.pdf.

Demerath III, N. J. (2004). The Pitfalls of Pluralism: Talibanization and Saffronization in India. Harvard International Review, 25(4), 16.

Fox, J., \& Sandler, S. (2003). Quantifying Religion: Toward building more effective ways of measuring Religious Influence On state-level behavior. Journal of Church and State, 45(3), 559-588.

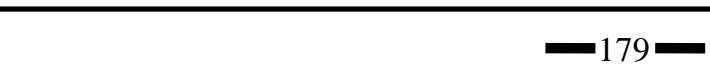


Fuller, C. J. (2000). The saffron wave: democracy and Hindu nationalism in modern India. vi. Journal of the Royal Anthropological Institute, 6(2), 367-367.

Galtung, J. (1996). Peace by peaceful means: Peace and Conflict, Development and Civilization. (Vol. 14). Sage. 70

Harris, F. C. (1994). Something within: Religion as a mobilizer of African-American political activism. The Journal of Politics, 56(1), 42-68.

Jaffrelot, C. (2015). The Modi-Centric BJP 2014 Election Campaign: New Techniques and Old Tactics. Contemporary South Asia 23 (2) 160-161. https://www.tandfonline.com/doi/citedby/10.1080/09584935.2015.1027662?scroll=top \&needAccess $=$ true

Jaffrelot, C. (Ed.). (2009). Hindu nationalism: A reader. Princeton University Press.

James, C. C., \& Özdamar, Ö. (2005). Religion as a factor in ethnic conflict: Kashmir and Indian Foreign Policy. Terrorism and Political Violence, 17(3), 447-467.

K, T. (2018, January 9). Difference Between Hinduism and Hindutva. Difference Between Similar Terms and Objects. http://www.differencebetween.net/miscellaneous/religionmiscellaneous/ifference-between-hinduism-and-hindutva/.

Lorenzen, D. N. (Ed.). (1995). Bhakti religion in North India: community identity and political action. State university of New York Press, 312.

Nadim, H (2019 February 20). "Demystifying Kashmir," The Interpreter. https://www.lowyinstitute.org/the-interpreter/demystifying-kashmir

Patnaik, A. \& Chalam, K.S.R.V.S. (1998). The Ideology and Politics of Hindutva. In Region Religion Caste Gender and Culture in Contemporary India. ed. T.V. Sathyamurthy. New Delhi: Oxford University Press, 266.

Ralph Winter, (1994, November 1). The Daunting Task of Hinduism, Mission Frontiers. http://www.missionfrontiers.org/issue/article/the-daunting-task-of-hinduism.

Rogers, M., \& Konieczny, M. E. (2018). Does religion always help the poor? Variations in religion and social class in the west and societies in the global south. Palgrave Communications, 4(1), 1-11. 


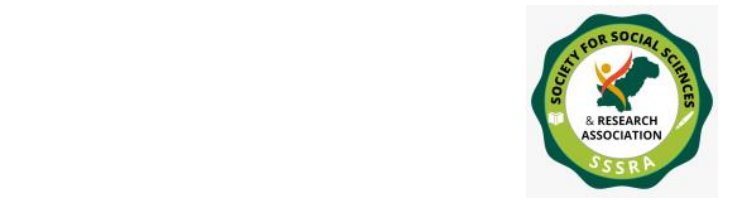

Sāvarakara, V. D. (1999). Hindutva: who is a Hindu? New Delhi: Hindi Sahitya Sadan, 32.

Sharma, A. (2002). On Hindu, Hindustān, Hinduism and Hindutva. Numen, 49(1), 1-36.

Retrieved July 9, 2021, from http://www.jstor.org/stable/3270470

Sharma, J. (2011). Hindutva: Exploring the idea of Hindu nationalism. Penguin Books India. 191.

Sharma, S. (2019, August 19). The Political Impact of India's Removal of Jammu \& Kashmir's Special Status. South Asian Voices. https://southasianvoices.org/understanding-the-political-impact-of-indias-removal-ofjammu-kashmirs-special-status/

Sharma, T.R. (1989). Religion and Politics in Modern India: A Historical Overview, In Religion Slate and Politics in India, ed. Moin Shakir. New Delhi, Ajanta Publications, 41.

Taseer, A. (2019). Can the World's Largest Democracy Endure Another Five Years of a Modi Government. Time. Retrieved on, 3. http://time.com/5586415/indiaelectionnarendra-modi-2019/.

The Nation Reporter (2020, January 26). World Starts Admitting Modi's Fascist Ideology: PM. The Nation, https://nation.com.pk/26-Jan-2020/world-starts-admitting-modi-sfascist-ideology-pm.

UCA. (n.d.) India/Jammu and Kashmir (1947-present), University of Central Arkansas. https://uca.edu/politicalscience/dadm-project/asiapacific-region/indiakashmir-1947present/

Vaishnav, M. (2018, October 11). What Is the Secret to the Success of India's Bharatiya Janata Party (BJP)?. Carnegie Endowment for International Peace. https://carnegieendowment.org/2018/10/11/what-is-secret-to-success-of-india-sbharatiya-janata-party-bjp-pub-77477.

Vaishnav, M. (2019). The BJP in power: Indian democracy and religious nationalism. Washington, DC: Carnegie Endowment for International Peace. https://carnegieendowment. org/files/BJP_In_Power_final. pdf.

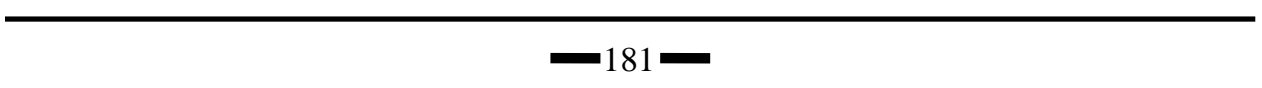


Walker, R. (2011). Hindutva: Indian nationalism and the politics of religious violence. in Believers in the Battlespace: Religion, Ideology and War, ed. Peter Harvey Denton. Ontario: Canadian Defense Academy Press. 119.

Worldview Stratfor. (2019, December 12). Kashmir Will Keep India and Pakistan at Risk of Conflict Again in 2020. Stratfor. https://worldview.stratfor.com/article/kashmir-willkeep-india-and-pakistan-risk-conflict-again-2020-modi 